\title{
CLOSED LANDFILL HEAVY METAL CONTAMINATION DISTRIBUTION PROFILES AT DIFFERENT SOIL DEPTHS AND RADIUSES
}

\author{
OTHMAN, R..$^{1 *}$ - MOHD LATIFF, N. H. ${ }^{1}-$ BAHARUdDIN, Z. M. ${ }^{1}-$ HASHIM, K. S. H. Y $.^{2}-$ \\ LUKMAN HAKIM MAHAMOD, L. H. ${ }^{3}$ \\ ${ }^{1}$ International Institute for Halal Research and Training (INHART) \\ Department of Landscape Architecture, Kulliyyah of Architecture and Environmental Design \\ (KAED), International Islamic University Malaysia, 53100 Kuala Lumpur, Malaysia \\ ${ }^{2}$ Department of Urban \& Regional Planning, Kulliyyah of Architecture and Environmental \\ Design (KAED), International Islamic University Malaysia, 53100 Kuala Lumpur, Malaysia \\ ${ }^{3}$ Department of Quantity Surveying, Kulliyyah of Architecture and Environmental Design \\ (KAED), International Islamic University Malaysia, 53100 Kuala Lumpur, Malaysia \\ Corresponding author \\ e-mail: rashidi@iium.edu.my; phone: +60-126-644-772; fax: +60-361-964-864
}

(Received 24 $4^{\text {th }}$ Jan 2019; accepted $3^{\text {rd }}$ May 2019)

\begin{abstract}
Various types of wastes are the main sources of heavy metal within a landfill system including metal waste components such as food cans, scrap metal, household hazardous waste and electronic waste such as batteries and old computers. The procedure that occurs inside the waste cells quickens that procedure for substantial metal draining from the waste component. This study comparing soil samples taken from four different sites in Selangor of closed non-sanitary (Sungai Kembong) and sanitary (Ampar Tenang, Air Hitam and Kubang Badak) landfills at different depths $(0-30 \mathrm{~cm}, 30-60 \mathrm{~cm}$ and $60-90 \mathrm{~cm})$ and radiuses (5-10 m, 10-15 m and 15-20 m), for ten heavy metals ( $\mathrm{Al}, \mathrm{Cr}, \mathrm{Mn}, \mathrm{Fe}, \mathrm{Co}, \mathrm{Ni}, \mathrm{Cu}, \mathrm{Zn}, \mathrm{Cd}$ and $\mathrm{Pb}$ ) to find the risk of heavy metal movement from the upper layer cell into the deeper layer. The data were analysed using ICP-MS (Perkin Elmer NexION 300X). Al and Fe displayed higher concentration at most of the sites with different volume of concentration at different depth and radius. Most of the sites consistently showed higher contamination in deeper soil than the upper layer of the soil.
\end{abstract}

Keywords: urban pollution, landfill, inorganic pollutant, laterite soil, leachate, municipal solid waste

\section{Introduction}

It is estimated that approximately 0.5 to $4.5 \mathrm{~kg}$ of solid waste per person per day is produced at different regions of the world (Bakare et al., 2005; Swati et al., 2014). Land degradation, which caused by human activities, creates significant adverse effects on the environments and ecosystems worldwide (Thomaz and Luiz, 2012; Bai et al., 2013; Li et al., 2013; Chen et al., 2015). Thus, solid waste becomes an important and emerging environmental problem. The most common ways to manage such waste disposal are landfills and incinerators. At the time being, it is up to $95 \%$ total of municipal solid waste (MSW) collected is disposed of in landfills worldwide (El-Fadel, 1997; Swati, 2014). Landfilling is the major MSW disposal method used in modern cities (Wong, 2015).

Due to the problems of environmental pollution and the shortage of urban land, landfill becomes a major issue in any urban management in the world (Hoornweg and Bhada, 2012). As consequences, ex-landfills are turned into another beneficial alternative to the urban population. At present, there were 143 closed landfills in Malaysia 
(SWCorp, 2017). The number of the closed landfills had increased each year from 115 in 2003 to 131 in 2012 and it has been expected to become 296 when all the existing landfills closed their operation in 2020 (Simis et al., 2016). For the time being, there are about 160 operating landfills and 143 closed landfills, which make altogether 303 landfills in total that, are available in Malaysia. It has been expected more than $70.0 \%$ of the future ex-landfills to be located in urban areas and become the major concern of the local population within the ex-landfill areas (Chun-Yang and Talib, 2006).

Based on Act 672 under Solid Waste and Public Cleansing Management Act 2007, every ex-landfill must undergo waste recovery through new technology such as waste to energy facilities, construction and demolition recovery facilities, organic waste facilities, landfill closure, and integrated waste management. However, the existence of the exlandfill within the neighbourhood reported creating issues of foul odours, leachate, and landfill gas pollution. The local communities have reported it and they claimed to have declined health and quality of life (Simis and Awang, 2015). These concerns probably have become more pragmatic when recent intensive studies demonstrated the increment of human health risk caused by exposure to toxic chemicals, such as dioxins and related compounds, and heavy metals in these dumping sites (Agusa et al., 2003; Minh et al., 2003).

Landfills containing hazardous materials are under critical observation today for potential hazards, resulting in the need for thorough risk analyses along with the soil and groundwater that have been contaminated with chemicals leaching from landfills. Several reports have been published which are documented on the leachate characterization and its effect on groundwater pollution (Boels and Fleming, 1993), but little information is available on the effect of landfills on soil contamination and its toxicological effects. Damaging human activities cause pollution. Thus, more information and assessment of land pollution are needed to overcome the problems occurred (Kardanpour et al., 2015; Mahmoud and El-Kader, 2015).

Based on the previous study, most organic chemical substances will eventually either be degraded through biochemical reactions in the landfill or be leached out of the landfill with water movement. However, the majority of heavy metals will remain in the landfill because heavy metal migration is very limited compared to the number of metals accumulated in the landfill (Oygard et al., 2004; Riber et al., 2005), especially in anaerobic processes. The slow movement of heavy metals is the result of heavy metals being subjected to strong sorption on soil particles, precipitation under anaerobic conditions, and chelation with inorganic and organic ligands in landfills (Bozkurt et al., 1999, 2000). Heavy metals occur naturally at low concentrations in soils. They are considered soil contaminants due to their widespread occurrence, as well as their acute and chronic toxicity (Youn-Joo, 2004).

High concentrations of heavy metal such as $\mathrm{As}, \mathrm{Cd}, \mathrm{Cu}, \mathrm{Pb}$, and $\mathrm{Zn}$ in soils have often been reported in a number of countries. It was reported by Bhattacharya (2012), that no significant adverse impacts of As upon human health in Bangladesh, India, and China. It is claimed that millions of people are potentially at risk from As poisoning. Similar to As, Cd accumulation in the offal of grazing animals in New Zealand and Australia made it unsuitable for human consumption. Besides, it affected access to meat products to overseas markets (Loganathan et al., 2008). There are also concerned about the urban development of horticultural sites which contained toxic levels of heavy metals in soils that resulting from excessive use of fungicides and herbicides (Pietrzak and Uren, 2011). 


\section{Materials and methods}

\section{Study area description}

Twelve points at 4 different sites of closed landfill located at Selangor, Malaysia namely; Ampar Tenang sanitary landfill (2॰49'13.3"N 101 $\left.40^{\prime} 47.6 " \mathrm{E}\right)$, Sungai Kembong non-sanitary landfill $\left(2^{\circ} 53^{\prime} 08.8^{\prime \prime} \mathrm{N} 101^{\circ} 49^{\prime} 17.0^{\prime \prime} \mathrm{E}\right)$, Air Hitam sanitary landfill $\left(2^{\circ} 52^{\prime} 22.4^{\prime \prime} \mathrm{N} 101^{\circ} 38^{\prime} 53.8^{\prime \prime} \mathrm{E}\right)$ and Kubang Badak sanitary landfill $\left(3^{\circ} 23^{\prime} 01.6^{\prime \prime} \mathrm{N}\right.$ $\left.101^{\circ} 24^{\prime} 54.2^{\prime \prime} \mathrm{E}\right)$ were selected for this study. The site selection was based on the types of the landfill and the size of the landfill located in Selangor state. Table 1 indicates the landfill sites info with the area covered, wasted collected, total year of operation and the current status of the landfill studied.

Table 1. Selected landfill sites with the area covered, waste collected per day, total year operation and current status

\begin{tabular}{c|c|c|c|c|c}
\hline LANDFILL SITES & $\begin{array}{c}\text { AREA } \\
\text { (ACRE) }\end{array}$ & $\begin{array}{c}\text { WASTE } \\
\text { COLLECTED } \\
\text { (TONE/DAY) }\end{array}$ & $\begin{array}{c}\text { TOTAL YEAR } \\
\text { OPERATION }\end{array}$ & $\begin{array}{c}\text { CURRENT } \\
\text { STATUS }\end{array}$ & SOURCE \\
\hline $\begin{array}{c}\text { Air Hitam Sanitary } \\
\text { Landfill }\end{array}$ & 100 & 1500 & 16 & Closed & $\begin{array}{c}\text { Othman et al. } \\
(2016)\end{array}$ \\
\hline $\begin{array}{c}\text { Kubang Badak Sanitary } \\
\text { Landfill }\end{array}$ & 30 & 400 & 10 & Closed & $\begin{array}{c}\text { Yahaya et al. } \\
(2016)\end{array}$ \\
\hline $\begin{array}{c}\text { Ampar Tenang Sanitary } \\
\text { Landfill }\end{array}$ & 10 & 100 & 9 & Closed & $\begin{array}{c}\text { Yusoff et al. } \\
(2013)\end{array}$ \\
\hline $\begin{array}{c}\text { Kampung Sungai } \\
\text { Kembong Inert Waste }\end{array}$ & 38.5 & 83 & 5 & Closed & $\begin{array}{c}\text { Yahaya et al. } \\
(2016)\end{array}$ \\
\hline
\end{tabular}

\section{Soil sampling}

Soil samples were collected at different points (0-200 mm depth, approx. $1000 \mathrm{~g})$ were taken by using soil auger (Eijkelkamp Agrisearch). The soil then was sealed in a polyethylene bag and labelled. The soil was dried in an oven for $70^{\circ} \mathrm{C}$ for 3 days to a week depending on the moistness of the soil. Then samples were ground by using agate mortar until becoming small particles. Then it was sieved using a $2 \mathrm{~mm}$ mesh to remove stones and plant materials. Then samples were stored at room temperature before being digested using Microwave Digestion Ethos D (Milestone, 2001). Heavy metals, Al, Cr, $\mathrm{Mn}, \mathrm{Fe}, \mathrm{Co}, \mathrm{Ni}, \mathrm{Cu}, \mathrm{Zn}, \mathrm{Cd}$, and $\mathrm{Pb}$ were then analysed by using ICP-MS (Perkin Elmer NexION 300X).

\section{Determination of Heavy Metals in Soils}

$0.5 \mathrm{~g}$ of soil samples were accurately weighed into a container made of PFA perfluoroalkoxy polymer and digested through a microwave digestion system using the digestion method as described by Zhao et al. (1994). Soil samples were air-dried and sieved. Soil samples were passed through a $2 \mathrm{~mm}$ sieve and ready for further analysis. Dried and the ground sample was mixed with $10 \mathrm{ml}$ of concentrated nitric acid $\left(\mathrm{HNO}_{3} 65 \%\right)$ and digested. Acid was added for each soil samples and then the digestion tubes were placed in a rotor segment by using a torque wrench. The segments were inserted into the microwave cavity and connected with the temperature sensor. The mixture temperature was adjusted to $\pm 175^{\circ} \mathrm{C}$ and 1,200 Watt of power for 30 minutes using Microwave Digestion (Milestone Start D) as detailed in Method US EPA 3051. The digestion was completed after the last solution was clear and no brownish fumes 
were released from the digestion vessel tubes. When digestion was completed, samples were removed and diluted. The soil digests were adjusted to the final volume of $50 \mathrm{~mL}$ with deionized water. This solution is further 1:1 diluted for the analysis of components by ICP-MS and divided into triplicate each into $15 \mathrm{ml}$ tubes.

\section{Data analysis}

All the experiments were carried out in triplicates and data presented as mean values of three independent replicates. Data were further analysed using analysis of variance (ANOVA). Statistical analysis for all experiments was performed by using SAS through factorial analysis of variance followed by Tukey's test with significant different at $P<0.0001$.

\section{Results and discussion}

\section{Ampar Tenang sanitary landfill}

The results in Fig. 1 showed heavy metal concentration in a closed sanitary landfill with a radius of 5 to $10 \mathrm{~m}, 10$ to $15 \mathrm{~m}$ and 15 to $20 \mathrm{~m}$ at different depth 0 to $30 \mathrm{~cm}, 30$ to $60 \mathrm{~cm}$ and 60 to $90 \mathrm{~cm}$ of Ampar Tenang sanitary landfill.

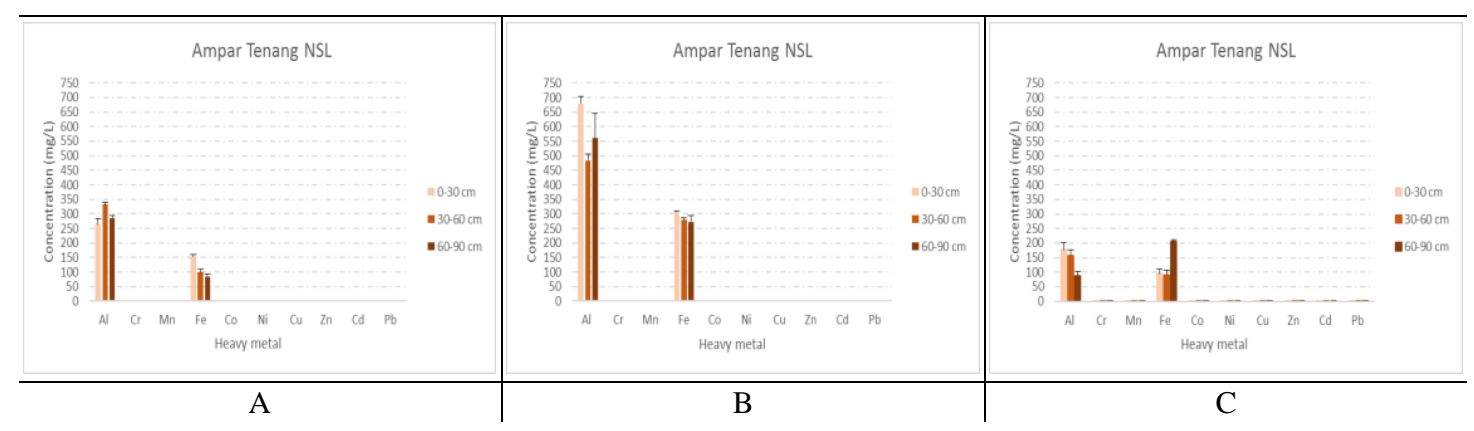

Figure 1. The pattern of 10 heavy metal concentration depicted Ampar Tenang sanitary landfill at different soil depths $(0-30 \mathrm{~cm}, 30-60 \mathrm{~cm}$, and $60-90 \mathrm{~cm})$ and radiuses $(A: 5-10 \mathrm{~m}, \mathrm{~B}: 10-15 \mathrm{~m}$ and $C: 15-20 \mathrm{~m}$ ) of the closed landfill

Results of heavy metal showed that $\mathrm{Al}$ and Fe concentration is higher at all point of Ampar Tenang landfill. Among the analysed heavy metals, Al and Fe concentration at radius 10 to $15 \mathrm{~m}$ had the highest concentrations. Each showed $679.088 \mathrm{mg} / \mathrm{kg}, 483.627$ $\mathrm{mg} / \mathrm{kg}$ and $560.437 \mathrm{mg} / \mathrm{kg}$ for Al while $306.678 \mathrm{mg} / \mathrm{kg}, 280.216 \mathrm{mg} / \mathrm{kg}$ and 272.183 $\mathrm{mg} / \mathrm{kg}$ for Fe. Concentration for the radius 5 to $10 \mathrm{~m}$ and 15 to $20 \mathrm{~m}$ also almost equal within each depth. The heavy metal concentration at radius 15 to $20 \mathrm{~m}$ showed $\mathrm{Al}$ range between $87.711 \mathrm{mg} / \mathrm{kg}$ and $177.155 \mathrm{mg} / \mathrm{kg}$ while for $\mathrm{Fe}$ the concentration range between $90.317 \mathrm{mg} / \mathrm{kg}$ and $204.819 \mathrm{mg} / \mathrm{kg}$. Meanwhile, radius 5 to $10 \mathrm{~m}$ showed $\mathrm{Al}$ concentration higher than Fe concentration. Each at $265.645 \mathrm{mg} / \mathrm{kg}, 332.441 \mathrm{mg} / \mathrm{kg}$, and $284.904 \mathrm{mg} / \mathrm{kg}$ for $\mathrm{Al}$ and $152.911 \mathrm{mg} / \mathrm{kg}, 99.968 \mathrm{mg} / \mathrm{kg}$ and $84.924 \mathrm{mg} / \mathrm{kg}$ for Fe.

\section{Sungai Kembong non-sanitary landfill}

The results in Fig. 2 showed heavy metal concentration in a closed non-sanitary landfill with a radius of 5 to $10 \mathrm{~m}, 10$ to $15 \mathrm{~m}$ and 15 to $20 \mathrm{~m}$ at different depth 0 to 
$30 \mathrm{~cm}, 30$ to $60 \mathrm{~cm}$ and 60 to $90 \mathrm{~cm}$ of Sungai Kembong non-sanitary landfill. Results of heavy metal showed that $\mathrm{Al}$ and $\mathrm{Fe}$ concentration is higher at all point of Sungai Kembong landfill. Among the analysed heavy metals, Fe concentration at radius 15 to $20 \mathrm{~m}$ showed $364.243 \mathrm{mg} / \mathrm{kg}, 534.058 \mathrm{mg} / \mathrm{kg}$ and $559.114 \mathrm{mg} / \mathrm{kg}$. Fe concentration at radius 15 to $20 \mathrm{~m}$ and 5 to $10 \mathrm{~m}$ also showed high concentrations. Each showed $170.397 \mathrm{mg} / \mathrm{kg}, 316.408 \mathrm{mg} / \mathrm{kg}$ and $436.530 \mathrm{mg} / \mathrm{kg}$ for radius 15 to $20 \mathrm{~m}$ while $337.625 \mathrm{mg} / \mathrm{kg}, 342.236 \mathrm{mg} / \mathrm{kg}$ and $289.030 \mathrm{mg} / \mathrm{kg}$ for radius 5 to $10 \mathrm{~m}$. The $\mathrm{Al}$ concentration showed the highest reading for radius 5 to $10 \mathrm{~m}$ at $160.216 \mathrm{mg} / \mathrm{kg}$, $185.739 \mathrm{mg} / \mathrm{kg}$ and $239.069 \mathrm{mg} / \mathrm{kg}$ compared to Al concentration at radius 10 to $15 \mathrm{~m}$ and radius 15 to $20 \mathrm{~m}$. For radius 10 to $15 \mathrm{~m}$, the concentration for $\mathrm{Al}$ range between $160.216 \mathrm{mg} / \mathrm{kg}, 185.739 \mathrm{mg} / \mathrm{kg}$ and $239.069 \mathrm{mg} / \mathrm{kg}$. Meanwhile, for radius 15 to $20 \mathrm{~m}$ showed a range between $28.183 \mathrm{mg} / \mathrm{kg}$ and $43.081 \mathrm{mg} / \mathrm{kg}$.

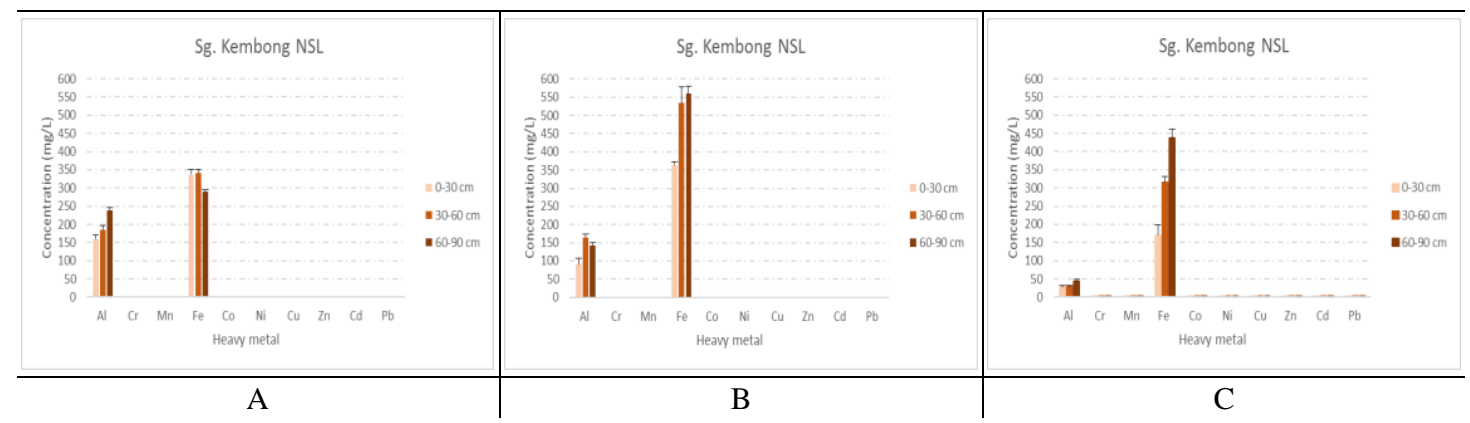

Figure 2. The pattern of 10 heavy metal concentration depicted Sungai Kembong non-sanitary landfill at different soil depths $(0-30 \mathrm{~cm}, 30-60 \mathrm{~cm}$, and $60-90 \mathrm{~cm})$ and radiuses $(A: 5-10 \mathrm{~m}, \mathrm{~B}$ : 10-15 $\mathrm{m}$ and $\mathrm{C}: 15-20 \mathrm{~m}$ ) of the closed landfill

\section{Air Hitam sanitary landfill}

The results in Fig. 3 showed heavy metal concentration in a closed non-sanitary landfill with a radius of 5 to $10 \mathrm{~m}, 10$ to $15 \mathrm{~m}$ and 15 to $20 \mathrm{~m}$ at different depth 0 to $30 \mathrm{~cm}, 30$ to $60 \mathrm{~cm}$ and 60 to $90 \mathrm{~cm}$ of Air Hitam sanitary landfill. Results of heavy metal showed that $\mathrm{Al}$ and $\mathrm{Fe}$ concentration is higher at all point of Air Hitam landfill. Among the analysed heavy metals, $\mathrm{Al}$ concentration at the radius 10 to $15 \mathrm{~m}$ showed the highest concentration. Each showed $235.604 \mathrm{mg} / \mathrm{kg}$ and $460.756 \mathrm{mg} / \mathrm{kg}$ and $422.434 \mathrm{mg} / \mathrm{kg}$. Meanwhile, radius 5 to $15 \mathrm{~m}$ and 15 to $20 \mathrm{~m}$ showed $87.317 \mathrm{mg} / \mathrm{kg}$, $75.733 \mathrm{mg} / \mathrm{kg}$ and $68.102 \mathrm{mg} / \mathrm{kg}$ for radius 5 to $10 \mathrm{~m}$ and $19.247 \mathrm{mg} / \mathrm{kg}, 42.861 \mathrm{mg} / \mathrm{kg}$ and $28.097 \mathrm{mg} / \mathrm{kg}$ for radius 15 to $20 \mathrm{~m}$. For Fe concentration, the highest concentration depicted by radius 15 to $20 \mathrm{~m} ; 523.195 \mathrm{mg} / \mathrm{kg}$ at 0 to $30 \mathrm{~cm}$ depth. Fe concentration at radius 10 to $15 \mathrm{~m}$ showed almost equal concentration at a different depth. Each showed $337.115 \mathrm{mg} / \mathrm{kg}, 270.938 \mathrm{mg} / \mathrm{kg}$ and $330.970 \mathrm{mg} / \mathrm{kg}$. Meanwhile for radius 5 to $10 \mathrm{~m}, \mathrm{Fe}$ concentration showed lower concentration at $107.231 \mathrm{mg} / \mathrm{kg}, 137.143 \mathrm{mg} / \mathrm{kg}$ and $136.536 \mathrm{mg} / \mathrm{kg}$ for each different depth.

\section{Kubang Badak sanitary landfill}

The results in Fig. 4 showed heavy metal concentration in a closed sanitary landfill with a radius of 5 to $10 \mathrm{~m}, 10$ to $15 \mathrm{~m}$ and 15 to $20 \mathrm{~m}$ at different depth 0 to $30 \mathrm{~cm}, 30$ to $60 \mathrm{~cm}$ and 60 to $90 \mathrm{~cm}$ of Kubang Badak sanitary landfill. Results of heavy metal showed that $\mathrm{Al}$ and $\mathrm{Fe}$ concentration is higher at all point of Kubang Badak landfill. 
Among the analysed heavy metals, Fe concentration depicted the highest concentration at the radius 15 to $20 \mathrm{~m}, 10$ to $15 \mathrm{~m}$ as well as radius 5 to $10 \mathrm{~m}$ of the radius. Each showed $471.797 \mathrm{mg} / \mathrm{kg}, 260.469 \mathrm{mg} / \mathrm{kg}$ and $103.413 \mathrm{mg} / \mathrm{kg}$ at radius 15 to $20 \mathrm{~m}$; $676.043 \mathrm{mg} / \mathrm{kg}, 618.660 \mathrm{mg} / \mathrm{kg}$ and $524.594 \mathrm{mg} / \mathrm{kg}$ at radius 10 to $15 \mathrm{~m}$ and $255.221 \mathrm{mg} / \mathrm{kg}, 268.966 \mathrm{mg} / \mathrm{kg}$ and $353.415 \mathrm{mg} / \mathrm{kg}$ at radius 5 to $10 \mathrm{~m}$. However, $\mathrm{Al}$ concentration showed the highest concentration depicted by radius 10 to $15 \mathrm{~m}$ and 5 to $10 \mathrm{~m}$. Each showed $359.564 \mathrm{mg} / \mathrm{kg}, 407.121 \mathrm{mg} / \mathrm{kg}$ and $289.186 \mathrm{mg} / \mathrm{kg}$ at radius 10 to $15 \mathrm{~m}$ while $332.316 \mathrm{mg} / \mathrm{kg}, 391.556 \mathrm{mg} / \mathrm{kg}$ and $342.372 \mathrm{mg} / \mathrm{kg}$ at radius 5 to $10 \mathrm{~m}$. Meanwhile, Al concentration at radius 15 to $20 \mathrm{~m}$ showed $172.183 \mathrm{mg} / \mathrm{kg}$, $121.184 \mathrm{mg} / \mathrm{kg}$ and $91.807 \mathrm{mg} / \mathrm{kg}$. Other heavy metal despite $\mathrm{Al}$ and $\mathrm{Fe}$ showed the lowest concentration at all radius and depth.

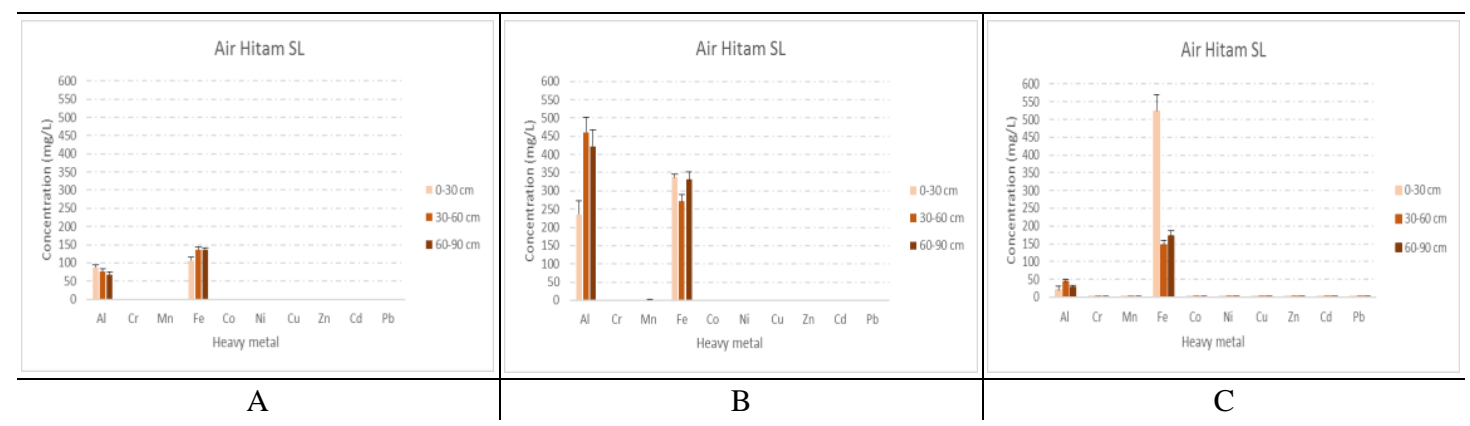

Figure 3. The pattern of 10 heavy metal concentration depicted Air Hitam sanitary landfill at different soil depths $(0-30 \mathrm{~cm}, 30-60 \mathrm{~cm}$, and $60-90 \mathrm{~cm})$ and radiuses $(A: 5-10 \mathrm{~m}, \mathrm{~B}: 10-15 \mathrm{~m}$ and $C: 15-20 \mathrm{~m}$ ) of the closed landfill

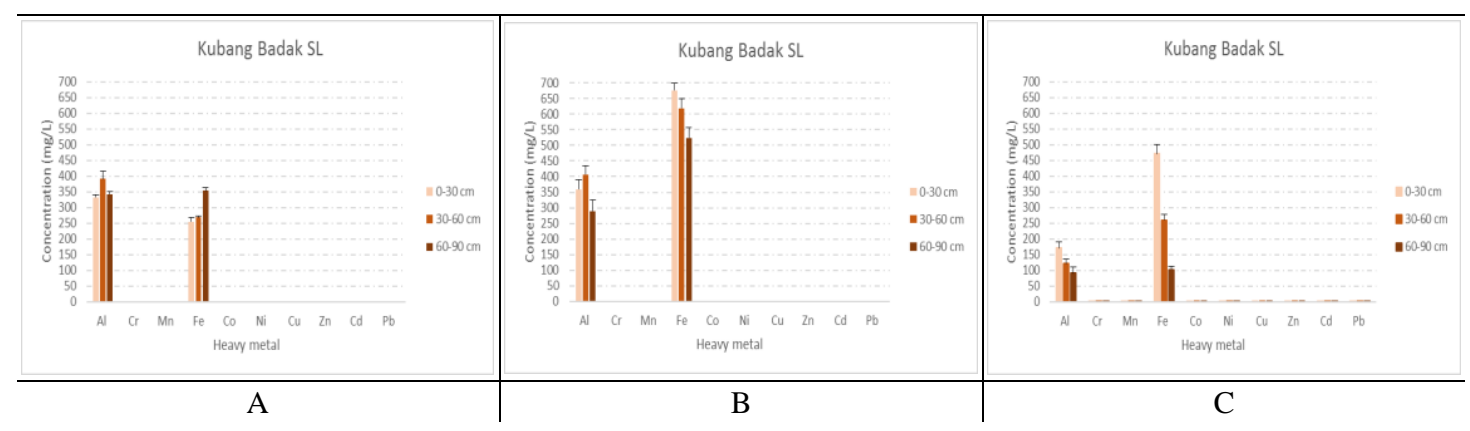

Figure 4. The pattern of 10 heavy metal concentration depicted Kubang Badak sanitary landfill at different soil depths $(0-30 \mathrm{~cm}, 30-60 \mathrm{~cm}$, and $60-90 \mathrm{~cm})$ and radiuses $(A: 5-10 \mathrm{~m}, \mathrm{~B}: 10-15 \mathrm{~m}$ and $C: 15-20 \mathrm{~m}$ ) of the closed landfill

Analysis of variance confirmed the findings by exhibiting highly significant differences $(P<0.0001)$ between the radius, depth, and heavy metal concentration at three different radiuses, three different depths, and ten heavy metals concentration. This clearly demonstrates that environmental factors and landfill area background can have an important influence on the accumulation of certain heavy metal and its content. Al and Fe concentration showed the highest pattern on all 4 closed landfill sites. Research by Elwali et al. (2008), showed that the most common heavy metal contaminations at the landfill area vary from iron $(\mathrm{Fe})$, cadmium $(\mathrm{Cd})$, copper $(\mathrm{Cu})$, zinc $(\mathrm{Zn})$ and nickel (Ni). Furthermore, various studies reveal very high contaminants levels in the 
groundwater underneath the non-engineered waste disposal sites in Selangor (Bahaaeldin et al., 2010; Suratman and Sefie, 2010; Taha et al., 2011). The subsurface soils were considerably polluted by heavy metals where wastes were dumped directly on top of the unlined natural formation (Mohd et al., 2013). This is probably the reason for the high concentration of the river alluvium soil beneath the landfill that has the highest metal concentrations of $\mathrm{Cu}, \mathrm{Zn}$ and $\mathrm{Pb}$ (Elwali et al., 2008). Based on the shallow and fluctuation of the periodic water table, water infiltration during the rainy season, acidic soil environment and local groundwater flow direction were the main reasons that enhanced the contamination migration through the soil formation into the groundwater (Elwali et al., 2008). Although the contamination present in the solid waste applied a significant impact on the groundwater, it has to be stressed that different metals behaved differently. Heavy metal binding properties of these soil constituents differ with the charges of the soil material and the ionic valences. As a result, different depths of the sample soil from landfill depict different capability of heavy metal binding. In addition, the rate and amount of pollutant penetration through the soil is also influencing the concentration of heavy metal present in the landfill environment.

\section{Conclusions}

The effects of the heavy metals content and composition, radiuses, depths and localities interactions have not been studied in the landfill area. Despite significant results in our understanding of heavy metals contamination distribution profiles at different soil depths and radiuses at closed landfill area, type of soil, the control mechanisms regulating the type of heavy metals distribution and accumulation and soil chemical reaction still remain an enigma. Each factor had an effect on the heavy metals content and profile; however, the most influential factor appeared to be a type of soil. Recommendations for future researches are by identifying the key factors controlling heavy metals distribution and accumulation in a different type of soils a greater understanding of landfill pollution mechanism in response to interactions with environmental factors will emerge.

Acknowledgements. The research was supported by the Ministry of Higher Education Malaysia (MOHE) and International Islamic University Malaysia (IIUM) under research grant PRIGS18-021-0021.

\section{REFERENCES}

[1] Agusa, T., Kunito, T., Nakashima, E., Minh, T. B., Tanabe, S., Subramanian, A., Viet, P. H. (2003): Preliminary on trace element contamination in dumping sites of municipal wastes in India and Vietnam. - Journal de Physique IV 107: 21-24.

[2] Bahaa-eldin, E., Rahim, A., Yusoff, I., Samsudin, A. R., Yaacob, W. Z. W., Rafek, A. G. M. (2010): Deterioration of groundwater quality in the vicinity of an active open-tipping site in West Malaysia. - Hydrogeology Journal 18: 997-1006.

[3] Bai, X. Y., Wang, S. J., Xiong, K. N. (2013): Assessing spatial-temporal evolution processes of karst rocky desertification land: indications for restoration strategies. - Land Degradation \& Development 24: 47-56.

[4] Bakare, A. A., Mosuro, A. A., Osibanjo, O. (2005): An in vivo evaluation of induction of abnormal sperm morphology in mice by landfill leachates. - Mutation Research-Genetic Toxicology and Environmental 582: 28-34. 
[5] Bhattacharya, S., Gupta, K., Debnath, S., Ghosh, U. C., Chattopadhyay, D., Mukhopadhyay, A. (2012): Arsenic bioaccumulation in rice and edible plants and subsequent transmission through food chain in Bengal basin: a review of the perspectives for environmental health. - Toxicological \& Environmental Chemistry 94: 429-44.

[6] Boels, D., Fleming, G. (1993): Chemical time bombs from landfills: appraisal and Modelling. - Land Degradation \& Rehabilitation 4: 399-405.

[7] Bozkurt, S., Moreno, L., Neretnieks, I. (1999): Long term fate of organics in waste deposits and its effect on metal release. - Science of the Total Environment 228: 135-152.

[8] Bozkurt, S., Moreno, L., Neretnieks, I. (2000): Long term process in waste deposits. Science of the Total Environment 250: 101-121.

[9] Chen, X. W., Tsz-Fung, W. J., Mo, W. Y., Man, Y. B., Wang-Wai, N. C., Wong, M. H. (2015): Ecological Performance of the Restored South East New Territories (SENT) Landfill in Hong Kong (2000-2012). - Land Degradation \& Development 1: 1-13.

[10] Chun-Yang, S. Y., Talib, M. (2006): Overview of brownfields in Malaysia. - Engineer Bulletin. Kuala Lumpur: Institute of Engineering Malaysia.

[11] El-Fadel, M., Findikakis, A. N., Leckie, J. O. (1997): Environmental impacts of solid waste landfilling. - Journal of Environmental Management 50: 1-25.

[12] Elwali, B-E. E. A. R., Yusoff, I., Samsudin, A. R., Yaacob, W. Z. W., Ghani, M. R. A. (2008): Heavy metal contamination of soil beneath a waste disposal site at Dengkil, Selangor, Malaysia. - Soil and Sediment Contamination 17: 449-466.

[13] Hoornweg, D., Bhada-Tata, P. (2012): What A Waste: A Global Review of Solid Waste Management. - Urban Development Series Knowledge Papers. No. 15. The World Bank.

[14] Kardanpour, Z., Jacobsen, O. S., Esbensen, K. H. (2015): Local versus field scale soil heterogeneity characterization - a challenge for representative sampling in pollution studies. - Soil 1: 695-705.

[15] Li, X. L., Gao, J., Brierley, G., Qiao, Y. M., Zhang, J., Yang, Y. W. (2013): Rangeland degradation on the Qinghai-Tibet Plateau: implications for rehabilitation. - Land Degradation \& Development 24: 72-80.

[16] Loganathan, P., Hedley, M. J., Grace, N. D. (2008): Pasture soils contaminated with fertilizer derived cadmium and fluoride: livestock effects. - Reviews of Environmental Contamination and Toxicology 192: 29-66.

[17] Mahmoud, E., El-Kader, N. A. (2015): Heavy metal immobilization in contaminated soils using phosphogypsum and rice straw compost. - Land Degradation \& Development 26: 819-824.

[18] Minh, N. H., Minh, T. B., Watanabe, M., Kunisue, T., Shinsuke, I., Tanabe, S., Sakai, S., Subramanian, A., Sasikumar, K., Viet, P. H., Tuyen, B. C., Tana, T. S., Prudente, M. S. (2003): Open dumping site in Asian developing countries: a potential source of polychlorinated dibenzo-p-dioxins and polychlorinated dibenzofurans. - Environmental Science and Technology 37: 1493-1502.

[19] Mohd, A. S. N., Yusoff, S., Piaw, C. Y. (2013): Soil chemistry and pollution study of a closed landfill site at Ampar Tenang, Selangor, Malaysia. - Waste Management \& Research: the Journal of the International Solid Wastes and Public Cleansing Association, ISWA 31(6): 599-612.

[20] Othman, R., Ali, Q. A. M., Ramya, R. (2016). Contamination composition of Fe, Mn and $\mathrm{Al}$ at 8 different profiles of solid waste disposal areas in Malaysia. - International Journal of Environmental Science and Development 7(5): 395-398.

[21] Oygard, J. K., Mage, A., Gjengedal, E. (2004): Estimation of the mass-balance of selected metals in four sanitary landfills inWestern Norway, with emphasis on the heavy metal content of the deposited waste and the leachate. - Water Research 38: 2851-2858.

[22] Pietrzak, U., Uren, N. (2011): Remedial options for copper contaminated vineyard soils. Soil Research 49: 44-55. 
[23] Riber, C., Fredriksen, G. S., Christensen, T. H. (2005): Heavy metal content of combustible municipal solid waste in Denmark. - Waste Management \& Research 23: 126-132.

[24] Simis, M., Awang, A. (2015): Planning for Ex-Landfill Redevelopment: Assessing What Community Have in Mind. - Asian Social Science 11(15): 136.

[25] Simis, M., Awang, A., Arifin, K. (2016): From Ex-landfill to Public Park: Impact on Local Community's Quality of Life and Living Environment. - Procedia-Social and Behavioral Sciences 222: 763-771.

[26] Suratman, S., Sefie, A. (2010): Groundwater contamination at landfill sites in Selangor. IAH, Krakow 2205-11.

[27] Swati, Ghosh, P., Das, M. T., Thakur, I. S. (2014): In vitro toxicity evaluation of organic extract of landfill soil and its detoxification by indigenous pyrene-degrading Bacillus sp. ISTPY1. - International Biodeterioration \& Biodegradation 90: 145-151.

[28] SWCorp (2017): Solid Waste Management and Public Cleansing Corporation. - Personal interview: Top Management Official.

[29] Taha, M. R., Yaacob, W. Z. W., Samsudin, A. R., Yaakob, J. (2011): Groundwater quality at two landfill sites in Selangor, Malaysia. - Bulletin of the Geological Society of Malaysia 57: 13-18.

[30] Tengku Ibrahim, T. N. B., Othman, F., Mahmood, N. Z. (2017): Assessment of water quality of Sembilang River receiving effluent from controlled municipal solid waste (MSW) landfill in Selangor. - International Technical Postgraduate Conference, IOP Conference Series: Materials Science and Engineering 210.

[31] Thomaz, E. L., Luiz, J. C. (2012): Soil loss, soil degradation and rehabilitation in a degraded land area in Guarapuava (Brazil). - Land Degradation \& Development 23: 7281 .

[32] Wong, M. H., Chan, Y. S. G., Zhang, C., Wang-Wai, N. C. (2015): Comparison of pioneer and native woodland species growing on top of an engineered landfill, Hong Kong: restoration program. - Land Degradation \& Development 2380.

[33] Yahaya, N. S., Lim, C. S., Taha, M. R., Pereira, J. J. (2016): Exposure of municipal solid waste disposal sites to climate related geohazards: Case study of Selangor. - Bulletin of the Geological Society of Malaysia 62: 57-63.

[34] Youn-Joo, A. (2004): Soil ecotoxicity assessment using cadmium sensitive plants. Environmental Pollution 127: 21-26.

[35] Yusoff, I., Alias, Y., Yusof, M., Ashraf, M. A. (2013): Assessment of pollutants migration at Ampar Tenang landfill site, Selangor, Malaysia. - Science Asia 39: 392-409.

[36] Zhao, F., McGrath, S. P., Crosland, A. R. (1994): Comparison of three wet digestion methods for determination of plant sulphur by inductively coupled plasma atomic emission spectroscopy (ICP-AES). - Communications in Soil Science and Plant Analysis 25: 407-418. 